\title{
Institutions, History and Wage Bargaining Outcomes: International Evidence from the Post-World War Two Era
}

Chris Minns $^{\mathrm{a}}$ and Marian Rizov ${ }^{\mathrm{b} *}$

${ }^{a}$ Department of Economic History, London School of Economics, London, United Kingdom;

${ }^{b}$ Department of Economics, Middlesex University Business School, London, United Kingdom

(Submitted $29^{\text {th }}$ September 2013; accepted 16 July 2014)

\begin{abstract}
This paper uses international evidence to assess the impact of tripartism and other forms of government involvement in bargaining on wage moderation and wage dispersion. We find that government involvement in wage bargaining leads to a modest increase in wage moderation and reduction in wage dispersion. Historic differences in bargaining institutions between countries have greater moderating effects.
\end{abstract}

Keywords: tripartism; labour market; wage bargaining; wage moderation; outcomes; institutions; TSCS data; econometric analysis

\section{Introduction}

Understanding how labour market institutions affect pay and employment outcomes is of longstanding interest to social scientists and policymakers. A major point of discussion has been the role of bargaining institutions in bringing about wage moderation and shaping the distribution of

${ }^{*}$ Corresponding author: Marian Rizov, Business School, Middlesex University, London NW4 4BT. M.rizov@mdx.ac.uk. 
earnings since the Second World War. Economic historians have argued that post-war arrangements facilitated wage moderation that fostered investment in productivity-enhancing mass production techniques. ${ }^{1}$ The extent of wage moderation, and critically, the depth of explicit government involvement in the bargaining process, varied significantly both between and within national economies, as the European post-war consensus eroded through the 1970s and 1980s, and new social pacts emerged in Ireland, the Netherlands, and other economies in subsequent decades. $^{2}$

Economists have offered several assessments of the relationship between bargaining structure and economic performance. ${ }^{3}$ This literature has mainly focused on the impact of the "centralisation" of bargaining on economic outcomes - whether negotiations take place at a "local" level, or between national unions and employer organizations. Scholars of industrial relations have identified a crucial shortcoming in this literature - the theoretical and empirical work to date has done little to disentangle the effects of different approaches used to target wage moderation. This is a particularly important issue when considering different bargaining practices and the changes in the macroeconomic environment facing negotiators in recent decades relative to the Golden Age of the 1960s and early 70s. ${ }^{4}$ States have differed in the roles played by three interest groups in negotiations over wages and working conditions: worker organizations (i.e. unions), employer organizations, and government. The early empirical literature on the effects of centralised or "corporatist" wage setting institutions paid little attention to how differences in the roles of these three groups of actors may or may not have impacted upon economic outcomes. ${ }^{5}$ Writings on comparative industrial relations suggest that direct government involvement may lead unions and employer organizations to accept wage bargains that would not arise through bilateral negotiations. ${ }^{6}$ The presence of government as an 
agent at the bargaining table could also serve as a device to encourage coordinated wage setting in the absence of highly centralised unions and employer organisations.

There is little direct evidence, however, on whether tripartism or other forms of government intervention in wage setting has actually led to wage moderation in recent decades. Wallerstein demonstrates that centralised wage bargaining correlates with pay inequality, but offers only a limited exploration of the detailed differences in bargaining institutions. ${ }^{7}$ Recent studies by Franz Traxler and Bernd Brandl have brought together a simple econometric framework with cross-country panel data to provide more explicit consideration of the role of bargaining institutions across countries and over time. ${ }^{8}$ This literature, however, has left several important questions unanswered. Research by Brandl with a more explicit focus on bargaining regimes has mainly looked at their effects on wage levels and labour costs, rather than the key dimensions of wage moderation and wage dispersion. A further issue is methodological: one would like to separate out the effects of bargaining state from country fixed effects, but this is made difficult by the slow evolution of bargaining regimes within countries. Finally, the focus on current institutions in explaining outcomes since 1970 has largely ignored the potentially persistent effects of cross-country differences in labour market institutions from earlier decades. Economic historians have debated the extent to which both industrial relations schemes and national wage and employment structures have deep historical roots, and studies to date have not attempted to quantify how the influence of past institutions on current norms and informal institutions compares to the effect of present-day formal institutions.

In this paper we use cross-country evidence to re-evaluate the influence of bargaining arrangements on post-1970 labour market outcomes. We focus on the effects of bargaining institutions on wage moderation and wage dispersion, which allows our results to speak to the 
debate between Eichengreen and co-authors, who argued that new bargaining methods led to wage moderation, versus scholars of industrial relations who claimed that centralised unions were able to secure larger wage increases for their members. Our analysis focuses on the role of government in the bargaining process, particularly through tripartite arrangements leading to negotiated social pacts. We develop a methodology that allows us to control for country fixed effects appropriately in the presence of slowly evolving bargaining states. Our findings show that government involvement in the wage bargaining process has a small, but statistically significant role in generating wage moderation and reduced wage dispersion. We also find that history mattered: bargaining institutions from the immediate post-war settlement continue to shape wage moderation and wage dispersion long after countries had shifted institutional regimes.

\section{Bargaining regimes and labour market outcomes: theory, evidence, and history}

Economic theory offers several arguments as to how the relative centralization of bargaining may affect wage outcomes. High level (often national) unions and employer organisations may internalize inter-firm or inter-industry tradeoffs that are external to negotiating parties under fragmented bargaining. Once wages are agreed, the centralised nature of labour market institutions is key to achieving wage moderation, by preventing shirking on agreements by either workers or firms. On the other hand, decentralised bargaining may bring about greater wage discipline in unions for whom higher wages will reduce demand for labour in the firms in which they are active. A further counterpoint is that centralised unions may be able to secure higher wage settlements if the effect of collective arrangements is mainly to increase the bargaining power of organised labour. 
Consistent with these opposing forces, Calmfors and Driffil argue for a U-shaped relationship between economic performance and the centralisation, with the effects of internalised spillovers in wage bargaining and fragmented union discipline dominating the tails of the bargaining distribution. ${ }^{9}$ Some empirical studies find evidence of a relationship between centralisation of bargaining and economic performance, through greater employment, moderated wage growth, and relative wage equalisation (Bruno and Sachs; Layard, Nickell and Jackman; Wallerstein), while others report ambiguous effects (OECD; Flanagan). ${ }^{10}$

A significant issue in this literature is how centralised or so-called "corporatist" bargaining is measured. Most follow Calmfors and Driffil by ranking countries on an index of centralisation of bargaining, based primarily on the "level" at which negotiations take place. ${ }^{11}$ Early studies typically based this measure on union structure - countries in which unions are mainly firm-specific rank as decentralised, while states with national confederations of unions are centralised. SOSKICE was among the first to observe that centralisation as measured does not necessarily overlap with the coordination of wage setting. ${ }^{12}$ In the 1980s (and indeed in subsequent decades as well), several states with "decentralised" firm-level bargaining according to Calmfors and Driffil actually feature high levels of wage coordination, due to the role of employer organizations, union governance, or links between bargaining partners and the government. $^{13}$

The last point is of particular interest here, as many industrial relations scholars have suggested that tripartite models which introduce the government as a bargaining partner could promote moderation and compression of the earnings distribution. Several reasons have been offered to support this prediction. Unions may agree to lower wage increases in exchange of concessions that are credible only when government is at the bargaining table. ${ }^{14}$ Others argue 
that revised tripartist models of wage moderation result from the implicit threat that if unions do not engage in negotiation on terms favoured by the government, tight monetary policy and austerity would result in high unemployment in the short term, with reduced wage settlements following in the longer run. ${ }^{15}$ A further possibility is that tripartism might be the device that provides wage coordination in the absences of national-level unions and employer organisations. Soskice suggests that guidance from central government encourages wage coordination in Japan; in the Singaporean case, an explicitly tripartite bargaining structure is inserted into a framework of relatively decentralised unions and employers. ${ }^{16}$ Other scholars have been sceptical of the ability of tripartite bargaining approaches to shift labour market outcomes. The ability of governments to transmit their intentions to labour market outcomes depends on the aptitude of government negotiators, their ability to successfully influence proceedings, and whether it is feasible to target real economic outcomes under uncertainty through an indirect mechanism such as wage bargaining. Democratically elected governments work within limited time horizons, dampening incentives to achieve moderation versus political economy considerations related to the electorate. Further, the emergence of tripartism or other models of consensual bargaining may occur at lower cost in some countries than in others. ${ }^{17}$

Empirical evidence regarding the importance of government involvement bargaining in explaining cross-country outcomes is limited. When separating government involvement from other institutional features of wage bargaining, Wallerstein found little support for the importance of government involvement, with the level of wage-setting dominating other measures of centralization. ${ }^{18}$ More recent research by Brandl finds empirical support for the notion that government intervention in wage bargaining has a substantial influence on nominal 
wages and labour costs, but he limits attention to developments post-1980, and the results do not speak directly to classic debates regarding wage moderation. ${ }^{19}$

A historical perspective may be necessary to develop a fuller understanding of the connection between bargaining arrangements and labour market outcomes. Flanagan asks whether patterns of negotiated wage settlements have more to do with national differences in culture and social norms, which themselves structure bargaining arrangements. ${ }^{20}$ Informal institutions or norms often have deep historical roots, which shape both the nature of formal institutions, and how those institutions are used to generate outcomes in the labour market and elsewhere. There may also be connections between past policy arrangements and current performance, with arrangements introduced in previous decades influencing current economic outcomes above and beyond any effects due to path dependency in the policy framework. Maier observes that both organised labour and (some) industrial capitalists saw advantages in publicly regulated wage negotiations prior to the First World War, and the impetus of wartime mobilization and economic dislocation during the 1920s and 1930s saw the emergence of early wage bargaining regimes that informed discussions after the Second World War. ${ }^{21}$ This view is supported by earlier work by Panitch, who connected the rise or post-war corporatism to the rising importance of full employment as a macroeconomic objective, particularly in light of the experience of mass unemployment of the 1930s. ${ }^{22}$ Early examples of successful social compacts (including widespread wage controls) are seen in smaller nation-states (particularly in Scandinavia), for which export production was key to economic performance, and where social democratic parties generally had a presence prior to $1945 .^{23}$ In West Germany, organised labour accepted wage restraint due to the primacy of reconstruction and post-war recovery that was in the interest of their members in the longer term. In short, the above explanations suggest that 
there may be a link between historical events and current labour market outcomes. In a related context, Acemoglu, Johnson, Robinson, and Thaicharoen argue that slow growth and economic volatility have more to do with deep historically generated institutions than current macroeconomic policy arrangements. ${ }^{24}$ It is an open question whether similar patterns might exist in terms of national wage structures in the face of the rise and fall of a host of wage bargaining arrangements.

The theory and evidence on bargaining coordination with and without direct government involvement suggest two testable hypotheses regarding the effect of bargaining institutions on wage settlements. First, (H1) if the coordination inspired by tripartite bargaining fosters wage moderation through the channels identified above, then one would hypothesise that state differences in government involvement in bargaining arrangements translate into state differences in wage moderation. If government participation in bargaining causes negotiators to account for inter-sectoral tradeoffs, it should also affect the wage dispersion between sectors in countries where tripartite arrangements are present. Second, and as argued earlier, current institutions may not be the end of the story. Norms and informal institutions related to historic bargaining systems may also affect current outcomes. A second hypothesis, therefore, emerges from the question of whether current labour market outcomes, in terms of wage moderation and wage dispersion, are affected by the historical legacy of the post-war settlement. Here the hypothesis (H2) is that "history mattered", with the test being whether states adopting more centralised bargaining regimes in the decades after the Second World War experiencing greater wage moderation and reduced wage dispersion from 1969 onwards. In the work that follows, we test the first hypothesis in some detail, and provide some exploratory empirical evidence to 
answer the second question. The results of this investigation also allow for an explicit comparison between the effects of current institutions and prior institutional arrangements.

\section{Labour market outcomes and bargaining arrangements, 1969-2008: the data}

We use contemporary evidence on wages and labour market institutions to evaluate the impact of bargaining arrangements on international labour markets. Our key indicators on labour market institutions are drawn from Visser, who provides cross-country evidence on the relative centralisation of bargaining, the role of government in wage setting, and the degree of centralisation and other wage rigidities in each nation state. ${ }^{25}$ Crucially for our analysis, the database captures both cross-sectional variation between countries and inter-temporal variation within countries over time. The wage bargaining information identifies major changes in national bargaining institutions over time, such as the examples of Ireland and the Netherlands discussed above. ${ }^{26}$ Comparable international wage data is drawn from the databases of the International Labour Organization (ILO). The ILO database provides wages for up to 10 sectors for most of the countries also covered by the labour market institutions database. Finally, to allow for an examination of trends in wage growth relative to productivity (a key point in any arguments regarding moderation, see Baccaro and Simoni ${ }^{27}$ ), we use statistical evidence on aggregate labour productivity from the Groningen Growth and Development Centre (GGDC) 10sector database. ${ }^{28}$ The data and sources used are described in further detail in the Appendix.

We focus on explaining two outcome measures that are in keeping with the existing (theoretical) literature on bargaining institutions. The first is the (real) wage-productivity gap, which we take as the ratio between wages and output per worker. This measure has obvious links to ideas regarding economic efficiency, as well as to the classic debate on wage moderation 
- if workers are accepting smaller wage increases so that firms can invest excess profits, this ratio should be smaller. The second outcome we examine is wage dispersion. Greater equity in wage outcomes is often an explicit aim of the actors engaged in wage negotiations, and ideally our results would speak to whether or not particular bargaining arrangements tend to achieve this aim. To compute the wage-productivity gap, we use sector-level wages for all countries and all years for which we have labour market data and evidence on bargaining institutions (as outlined below), and divide these by national output per unit of labour. ${ }^{29} \mathrm{We}$ use the standard deviation of the sectoral wage observations in the country in each year as our wage dispersion measure. ${ }^{30}$ The wage data used refer to ILO series that combine male and female workers. We have much wider country coverage in observations that combine both genders than for only male or only female workers, but the data suggest similar patterns (and in particular similar regression results) if we extend coverage to all available data.

Table 1 summarizes wage and labour productivity statistics for the 22 countries included in our sample. The summary statistics for the spread of earnings from the ILO data are well in line with other estimates of the earned income distribution for these countries. In terms of real hourly wages and output, Canada, Denmark, Netherland, Norway, and Switzerland are near the top of the rankings, with Greece, Portugal, Singapore, and Israel located near the bottom. These figures do not account for changes in wages over time, differences in sectoral composition between countries, and the timing of any missing observations. Canada, Great Britain, and the United States exhibit relatively high wage dispersion, while Japan, Singapore, New Zealand, and the Nordic economies are towards the other end of the spectrum.

(Table 1) 
We generate a series of contemporary wage bargaining categories based on two of Visser's variables as bargaining dimensions: first, the extent of government involvement in wage negotiations (government imposes wage settlements, tripartist negotiations, indirect government involvement, no government involvement) and second, the level at which most wage bargaining occurs (national, industry-level, or local). ${ }^{31}$ As the wage data we use is not disaggregated within sectors and we cannot separate industry from firm (local) level effects, we focus mainly on differences between national bargaining relative to the alternatives. Furthermore, considering the importance and sensitivity of bargaining arrangements measures discussed in the literature, we pay special attention to the government involvement dimension. We use Mokken's nonparametric scaling model to compute a synthetic index of item scores (by level of government involvement) forming a scale with the highest possible Loevinger's H-coefficient of homogeneity as the primary scaling criterion. ${ }^{32}$ The threshold value for the H-coefficient is 0.30 and higher values indicate a strong scale. We find that a scale with three categories (government imposes wage settlements, tripartist negotiations, and indirect or no government involvement) performs the best with $\mathrm{H}=0.49$ while the reliability of the scale as measured by Cronbach's Alpha is 0.72 , above the threshold of 0.70 . Based on this sensitivity analysis and taking into account the information available in Visser's codebook we select a set of three dummy variables (government imposed wages, tripartist negotiations, and indirect or no government involvement) to measure government involvement in wage setting and a dummy variable (national level bargaining vs. the alternatives) to control for the level at which wage bargaining occurs.

We also use data on historic bargaining institutions from Allard and Lindert. ${ }^{33}$ This consists of a single national indicator related to bargaining coordination (corporatism index) from the immediate post-war period, between 1950 and 1960. Historic bargaining arrangements 
might be used as an instrument for current bargaining state if the researcher is worried that the second of these is endogenous, but a more compelling argument is that, as discussed earlier in this paper, the regimes enacted following the end of the Second World War have long-term effects. The new institutions introduced after the deep shocks of the Second World War may have long-run effects on norms and informal institutions that take several generations to fade from public practice. A second possibility is that bargaining arrangements circa 1950 reflect long-run differences in formal or informal institutions prior to the Second World War that are likely to have persistent effects. Summary statistics for national bargaining regimes are provided in the Appendix, Table A1.

Table 2 presents summary statistics of wage and productivity trends by bargaining state using our preferred measures. The top panel of the table shows clear differences in wages and wage dispersion depending on the relative centralisation of wage bargaining. National-level bargaining produces smaller (sectoral) wage gaps than bargaining focused at industry or local levels. This pattern is well in line with existing theories related to the internalisation of crosssectoral spillovers in the bargaining process when bargaining occurs at the national level. Differences in real wages and productivity are similarly associated with the level of bargaining. Real hourly wages and labour productivity are lower where national-level bargaining exists, but the relationship with the wage-productivity gap is the opposite. We also find differences in wage dispersion for different levels of government involvement in the bargaining process. Dispersion is greatest when the government plays no direct role in bargaining, falling significantly when government becomes active partners in determining wage outcomes. While the ranking in wages and productivity by extent of government intervention is less obvious, the pattern for the wage- 
productivity gap suggests that the intermediate category of government involvement, in tripartite negotiations, delivers the most wage moderation.

(Table 2)

\section{Statistical methodology and estimation results}

We develop statistical models to explore four research questions linked to the two hypotheses outlined earlier. The first two questions relate to the effects of current bargaining arrangements (H1):

a) Were cross-country differences in government involvement in bargaining associated with differences in wage moderation between 1969 and 2008 ?

b) Were cross-country differences in government involvement in bargaining associated with differences in wage dispersion between 1969 and $2008 ?$

The next two questions evaluate the hypothesis regarding historical institutions and current wage outcomes (H2):

c) Did post-Second World War bargaining arrangements have long-term effects on wage moderation that persist into the period between 1969 and 2008 ?

d) Did post-Second World War bargaining arrangements have long-term effects on wage dispersion that persist into the period between 1969 and 2008 ?

To answer questions a) and b), we estimate a series of regressions linking wage outcomes to bargaining arrangements. In regressions explaining wage moderation, the model takes the following form:

$$
Y_{i j t}=\beta_{0}+\beta_{1} t+\beta_{2} N_{i t}+Z_{i t} \gamma+s_{j} \delta+c_{i} \theta+u_{i j t} \sigma+X_{i t} \mu
$$


In equation (1), $\mathrm{Y}_{\mathrm{ijt}}$ is the labour market outcome of interest observed in country $\mathrm{i}$, sector $\mathrm{j}$, and year $\mathrm{t}$. On the right-hand side, we include a constant term $\left(\beta_{0}\right)$, a time trend $(\mathrm{t})$, and indicator for national level bargaining $\left(\mathrm{N}_{\mathrm{it}}\right)$, a vector of government involvement states $\left(\mathrm{Z}_{\mathrm{it}}\right)$ - as with bargaining, these are common across sectors, sets of dummies for sector $\left(\mathrm{s}_{\mathrm{j}}\right)$ and country $\left(\mathrm{c}_{\mathrm{i}}\right)$, a set of dummies for the original unit of pay ${ }^{34}\left(\mathrm{u}_{\mathrm{ijt}}\right)$ which varies across sectors in some countries, and a vector of other national, time-varying controls $\left(\mathrm{X}_{\mathrm{it}}\right) .{ }^{35}$ Our main interest in the baseline regression in (1) is the sign and magnitude of the coefficients $\beta_{2}$ and $\gamma$ measuring the effects of bargaining states $\mathrm{N}$ and $\mathrm{Z}$. In accordance with our research questions, and consistent with much of the existing literature, we focus on the effects of bargaining regimes on two direct measures of labour market outcomes associated respectively with notions of moderation - the wageproductivity gap, and equity - the dispersion of real hourly wages. In the model of wage dispersion, the dependent variable becomes $\mathrm{Y}_{\mathrm{it}}$, as dispersion is the observed standard deviation among the industry wages in each country/year cell.

The discussion in previous sections illustrated how we might expect both differences in bargaining regimes and differences in country-specific institutions to cause differences in labour market outcomes. We adopt a simple empirical strategy to distinguish between these two sources of differences in labour market outcomes. Based on annual industry - country observations we employ TSCS (time-series and cross-section) techniques. The estimation is complicated because of the nature of the main variables of interest in our analysis - the bargaining regime dummies $(\mathrm{H}$ and $\mathrm{Z}$ ) - that have little within-country variance and show much more variation across countries than over time. The fixed country effects are likely to soak up most of the explanatory power of the slowly changing bargaining regime indicators. This aggravates the inefficiency of the fixed effects estimator and may lead to unreliable point 
estimates that would then lead to incorrect inferences in the same way that a biased estimator could. Therefore, we employ four estimators to identify and address possible biases: pooled ordinary least squares (OLS) with robust standard errors, fixed effects (FE), random effects (RE), and Hausman-Taylor (HT). ${ }^{36}$ In the Appendix we discuss in detail the advantages and disadvantages of each of the estimators employed.

For questions c) and d), we extend the Hausman-Taylor estimation of equation (1) for wage moderation (and similarly when explaining wage dispersion) with the addition of a measure of historical bargaining institutions (the corporatism index):

$$
Y_{i j t}=\beta_{0}+\beta_{1} t+\beta_{2} R N_{i t}+R Z_{i t} \gamma+H_{i} \pi+s_{j} \delta+c_{i} \theta+u_{i j t} \sigma+X_{i t} \mu,
$$

where $\mathrm{H}_{\mathrm{i}}$ refers to historic bargaining institutions and $\pi$ is the effect of these institutions on current outcomes, all else equal. $\mathrm{RN}_{\mathrm{it}}$ and $\mathrm{RZ}_{\mathrm{it}}$ are residuals estimated from auxiliary regressions following ideas in Plümper and Troeger where we decompose the contemporary bargaining regime indicators total effects into a fixed (historic) effect and a time-varying policy innovation effect, captured by the residuals. ${ }^{37}$ Results from the auxiliary regressions are reported in the Appendix, Table A2.

(Table 3)

Table 3 presents regression results linking the wage-productivity gap to bargaining state. We also include controls for national income (in the form of GDP per capita in '000 PPP Dollars), a time trend, and the salary or wage unit used in the original source data. ${ }^{38}$ The OLS specification in column (1) shows significant differences in the wage-productivity gap associated with bargaining regimes. Consistent with the summary statistics in Table 2, tripartite arrangements are associated with significant wage moderation. The sign on the coefficient for 
government imposed wage settlements is also negative, but is small in magnitude and falls well short of statistical significance. We also find little effect here of the level of bargaining, which has a positive sign but is estimated imprecisely. Many of the states with some form of government involvement in wage negotiations also have national-level bargaining, so this pattern of coefficients mainly reveals that level of negotiations has little additional effect - once government actors are part of the process they serve as the primary coordinating device. The results see reduction in coefficient magnitude in column (2), where we estimate a fixed-effects (FE) model with controls for sector and country. The coefficient on tripartism is reduced by about one half, but it remains statistically significant at the one percent level. This pattern continues in the random-effects (RE) regressions shown in column (3). The results are consistent with our discussion on the characteristics of the estimation methods employed. Thus the OLS estimates in column (1) represent the upper bound of the magnitude of the effects of interest while the FE (and RE) models generate more conservative estimates forming the lower bound. The final model in Table 3 is the Hausman-Taylor (HT) estimator, in which bargaining states are treated as potentially endogenous time-varying regressors. Reassuringly, the results are quite similar to what we find in the other specifications - in particular, the coefficient on the effect of tripartite bargaining remains significant and of a similar order of magnitude.

Furthermore, the Hausman specification test yields values of around 2 and do not reject the null hypothesis that the instruments and the fixed effects are uncorrelated. ${ }^{39}$

(Table 4)

Table 4 presents results from a similar series of regression models, with national wage dispersion as the dependent variable. The OLS specification without country controls (column 1) shows large differences among bargaining regimes. Countries with government imposed 
wage settlements have much less wage dispersion than elsewhere, however tripartism is not associated with significantly more wage compression than more liberal bargaining regimes. The addition of country fixed effects has little impact on the coefficient on government imposed wage outcomes which remains statistically significant. The results from the RE model also show that there is little between-variation left once we add the country controls; thus, the RE results can be considered equivalent to the OLS results with country controls. The pattern persists through to the Hausman-Taylor (HT) estimates, where the coefficient on tripartite negotiations has a similar magnitude to the fixed and random effects models, and is just short of statistical significance with a t-statistic of about 1.5. A further interesting result is that national level bargaining does not appear to lead to reduced wage dispersion in the models in columns 1 to $4 .^{40}$

\section{(Table 5)}

The results presented thus far show that current bargaining regimes do matter for wage moderation, a finding that persists after a range of approaches to control for (unobserved) institutional effects and the possible endogeneity of the bargaining regimes. For wage dispersion, we find that tripartite models do not have as clear an effect, suggesting that the influence of government in negotiations is more often to suppress the level of overall wage growth, rather than to target different sectors based on current levels of pay. In Table 5, we extend our baseline models to directly explore the role of historical institutions in shaping labour market outcomes in the present day. We estimate equation (2) introduced earlier using the Hausman-Taylor methodology, which allows us to contrast the effects of historic wage coordination measures from 1950s with the effects of contemporary bargaining regimes. Following ideas set out by Plümper and Troeger, we use the residuals estimated from auxiliary regressions of present bargaining regime on the historical (time invariant) coordination indicator 
as the right-hand side variable to capture the effects of time-varying changes (innovation) in national bargaining institutions beyond the impact of their historic predecesors. ${ }^{41}$ This approach yields two main findings. First, the marginal effects of government involvement in wage setting (tripartism or government imposing wages, respectively) are much as we found in earlier models that control for country and industry factors through fixed effects and other approaches, and these coefficients are significant at the 1 percent level. Second, we find large, significant effects of historic wage coordination, which dominates the impact of current bargaining institutions. These results suggest that both current bargaining regimes and historical institutions matter in understanding international differences in wage moderation. National choice of the formal institutional framework in which bargaining takes place today does appear to have observable effects on wage moderation and dispersion, but the institutional setup found in the immediate post-war era (which in many countries reflected the strength of organized labour and the importance of central government even earlier in the twentieth century) casts a large shadow on outcomes in the present day.

\section{Discussion and conclusions}

The entrance of government into wage bargaining is one of the major developments in global industrial relations in the last 65 years. Differences in institutional frameworks and national policies regarding wage bargaining are often identified as a source of variation in wage structures between countries. This paper seeks to achieve two aims: first, to bring a new methodological approach to the question at hand that provides robust evidence regarding the relationship between government involvement in bargaining arrangements and wage outcomes, and second, evaluate whether past institutions continue to shape bargaining outcomes in the present day. We 
find some support of our first hypothesis (H1) that tripartism and other forms of government intervention in the bargaining process have consistent, but modest effects on labour market outcomes. Wage moderation is greater in the presence of tripartism, with workers accepting wage increases that are lower relative to productivity growth, as compared to states without government involvement in bargaining. Wage dispersion is much less affected by tripartite bargaining, which suggests that the influence of government may have been primarily on overall wage levels, rather than targeting the pay of particular sectors.

Historical bargaining arrangements, measured here as the degree of corporatism in national labour markets in the immediate post-war settlement between 1950 and 1960, appear to have larger effects than current institutions - a finding strongly in support of our second hypothesis (H2). One explanation for this finding is that post-Second World War arrangements reflect labour market "culture" in the early twentieth century, something that is observed to some extent in terms of international differences in work time and work sharing over the long run. ${ }^{42}$ Alternatively, one could argue that the Second World War served as a form of structural break in the national labour markets under consideration. Subsequent changes in bargaining institutions matter on the margin, as our results indeed show, but expectations surrounding acceptable negotiated pay outcomes are strongly related to the institutional framework that operated when formal industrial relations first emerged as an important feature of many economies in the early 1950s.

What lessons do these findings carry for governments and policy makers in the present day? The first one is: know your history. Negotiated wage outcomes depend on the interaction of formal and informal institutions in the bargaining arena. If informal institutions are strongly dependent on behaviour conditioned by significant changes in bargaining arrangements that 
emerged circa 1950, then it is relatively unsurprising that reshaping bargaining arrangements today has a relatively small effect on the structure of pay. The second lesson we would draw is that "critical junctures" 43 matter. The Second World War was a major international shock that permitted the entrance of government into what were previously private labour markets both during and after the conflict. The changes that occurred during that critical juncture continue to have ongoing ramifications for how workers are paid today, even in markets where governments have largely withdrawn from the formalities of bargaining.

\section{Notes}

1. Eichengreen and Iversen, "Institutions and Economic Performance"; Eichengreen and Vazquez, "Institutions and Economic Growth".

2. Wallerstein, Golden, and Lange argue that wage-setting remained centralised in much of Northern and Central Europe despite the institutional changes of the 1980s and 1990s. Wallerstein, Golden, and Lange, "Unions, Employers and Wage-Setting".

3. Calmfors and Driffil, "Bargaining Structure"; Nickell and Layard, "Labor Market Institutions"; Freeman, "Labor Market Institutions"; OECD, Employment Outlook, Chapter 3. For evidence on the connection between tripartite bargaining structures and the welfare state, see Siegel. Siegel,

“'Competitive Concertation"”

4. Soskice, "Wage Determination"; Flanagan, "Macroeconomic Performance".

5. One exception is Wallerstein, who uses information on government involvement in his model of wage dispersion (defined using the tails of the wage distribution) reported in the OECD Employment Outlook. Wallerstein, "Wage-Setting Institutions and Pay".

6. Hassel, "Politics of Social Pacts"; Visser, "Two Cheers for Corporatism". 
7. Wallerstein, "Wage-Setting Institutions and Pay".

8. Traxler and Brandl, "Collective Bargaining”; Brandl, "Successful Wage Concentration”.

9. Calmfors and Driffil, "Bargaining Structure".

10. Bruno and Sachs, Economics of Worldwide Stagflation; Layard, Nickell, and Jackman,

Unemployment; Wallerstein, "Wage-Setting Institutions and Pay"; OECD, Employment Outlook, Chapter

3; Flanagan, "Macroeconomic Performance".

11. Calmfors and Driffil, "Bargaining Structure".

12. Soskice, "Wage Determination".

13. Calfmors and Driffil, "Bargaining Structure"; Baccaro and Simoni, "Organizational Determinants of Wage Moderation".

14. These concessions might include reduced taxes paid by employees, and union involvement in public policy through the operation of training and certification programmes. Visser, "Two Cheers for Corporatism"; Hassel, "Politics of Social Pacts".

15. Hassel, "Politics of Social Pacts". Visser presents a related argument for the Netherlands; following major central accords in 1982 and 1993, bipartite negotiations took place with knowledge that government would be likely to return to the bargaining table should employment changes designed to achieve wage moderation stall. Visser, “Two Cheers for Corporatism”. See also Hassel for further discussion on how social pacts have been sustained in European economies. Hassel, "Policies and Social Pacts".

16. Soskice, "Wage Determination", 41.

17. For example, German wage bargaining typically takes place within industries at the regional level, without national oversight. Soskice, "Wage Determination", 44.

18. Wallerstein, "Wage-Setting Institutions and Pay".

19. Brandl, "Successful Wage Concentration".

20. Flanagan, “Macroeconomic Performance”. 
21. Maier, "Preconditions for Corporatism". See Gerber on the impact of the First World War on the relative appeal of corporatism in the United States and the United Kingdom. Gerber, "Corporatism in Comparative Perspective".

22. Panitch, "The Development of Corporatism".

23. See Alexopoulos and Cohen for more detail on the history of Swedish centralised bargaining. Alexopoulos and Cohen, "Centralised Wage Bargaining".

24. Acemoglu et al., "Institutional Causes".

25. Visser, "ICTWSS Database".

26. Baccaro and Simoni, "Centralized Wage Bargaining"; Visser, "Two Cheers for Corporatism”.

27. Baccaro and Simoni, "Organizational Determinants of Wage Moderation".

28. A second database is available that includes sectoral data for a limited number of countries; we have not used this so far as we would lose much of the compelling variation in labour market institutions.

29. Ideally we would use sector-based national income estimates here, but they are available over time only for a small set of countries, which do not include many of the states with the more interesting institutional histories.

30. We have also tried alternatives such as the mean absolute deviation within each country year cell, or the ratio between "skilled" and "unskilled" sectors. These approaches yield quantitatively similar results. 31. The wage coordination in the Visser database is highly collinear with bargaining level, and analysis with that measure yields similar results. Visser, "ICTWSS Database".

32. Hemker, Sijtsma, and Molenaar, "Selection of Unidimensional Scales"; Mokken and Lewis, “A Nonparametric Approach".

33. Allard and Lindert, "Euro-Productivity and Euro-Jobs".

34. While we have converted all monthly, daily, and weekly salaries and wages into hourly form, there may be compensating differences associated with differences in contractual form, or other unobserved differences between pay period and earnings. 
35. The Appendix outlines how we converted series with different currencies and contract form on the most consistent basis possible. In exploratory regressions we included a series of controls for whether original pay was reported monthly, weekly, daily, or hourly, but these are statistically insignificant and their inclusion has little effect on the other coefficients. We also experimented with controls for whether series were based on the wages of male workers, female workers, or a mix of the two; in the results that follow, we present findings based on the final set of series (it contained by far the most observations). Results are broadly similar in the gender-specific data, and we have also estimated models which pool the series and include series type controls, with little change on the overall results.

36. Hausman and Taylor, "Panel Data and Unobservable Individual Effects".

37. Plümper and Troeger, "Efficient Estimation".

38. We have experimented with union density as an additional explanatory variable in alternative specification of this model. It is at best an imperfect proxy for the importance of labour organizations on national bargaining structures, and is not available consistently for all countries in our analysis. Nevertheless, the inclusion or exclusion of this variable has little effect on other coefficients. In additional regression we have interacted union density with bargaining institutions, but these interactions almost universally fall far short of statistical significance, and fail to add much of substance to the overall picture.

39. Overall, the standard errors appear smaller compared with the RE ones because our HT estimator does not allow for robust standard errors. As a robustness check we also estimated FEVD models and the results were similar to the HT results reported. Because our sample size is quite large we chose to report the HT results given that the FEVD estimator is originally developed for small sample TSCS data. 40. To address concerns about serial correlation in variables run all models estimated thus far on transformed data of five-year averages as we then have 8 periods in total; the results remain stable and very similar to the ones reported.

41. Plümper and Troeger, "Efficient Estimation”. 
42. Huberman and Minns, “'The Times They Are not Changin"”. More broadly, our findings can be seen relevant to the debate on the link between tripartism and the varieties of capitalism theory. For example, Regini, “Tripartite Concertation”. The policy implication of such link is that ideas of designing or redesigning the institutions of European industrial relations should be considered with caution as found, for example, by Schroeder and Weinert in a related context. Schroeder and Weinert, "Designing Institutions".

43. Acemoglu and Robinson, Why Nations Fail.

44. Source at http://www.oanda.com/currency/historical-rates-classic.

45. US Department of Labor, Bureau of Labor Statistics, ftp://ftp.bls.gov/pub/special.requests/cpi/cpiai.txt.

46. Allard and Lindert, "Euro-Productivity and Euro-Jobs".

47. Hausman and Taylor, "Panel Data and Unobservable Individual Effects"; Plümper and Troeger, "Efficient Estimation".

48. Hsiao, Analysis of Panel Data.

\section{Bibliography}

Acemoglu, D., S. Johnson, J. A. Robinson, and Y.Thaicharoen. "Institutional Causes, Macroeconomic Symptoms: Volatility, Crises and Growth.” Journal of Monetary Economics 50, no. 1 (2003): 49-123.

Acemoglu, D, and J. A. Robinson. Why Nations Fail: The Origins of Power, Prosperity, and Poverty. London: Profile Books, (2012).

Alexopoulos, M, and J. Cohen. "Centralised Wage Bargaining and Structural Change in Sweden." European Review of Economic History 7, no. 3 (2003): 331-363. 
Allard, G, and P. H. Lindert. "Euro-Productivity and Euro-Jobs since the 1960s: Which Institutions Really Mattered?” NBER Working Paper 12460, (2006).

Baccaro, L, and M. Simoni. "Centralized Wage Bargaining and the "Celtic Tiger" Phenomenon.” Industrial Relations 46, no. 5 (2007): 426-455.

Baccaro, L, and M. Simoni. “Organizational Determinants of Wage Moderation.” World Politics 62, no. 4 (2010): 594-635.

Brandl, B. "Successful Wage Concentration: The Economics Effects of Wage Pacts and their Alternatives.” British Journal of Industrial Relations 50, no. 3 (2012): 482-501.

Bruno, M, and J. D. Sachs. Economics of Worldwide Stagflation. Chicago: NBER Books, (1985).

Calmfors, L, and J. Driffill. "Bargaining Structure, Corporatism and Macroeconomic Performance.” Economic policy 3, no. 6 (1988): 13-61.

Eichengreen, B, and T. Iversen. "Institutions and Economic Performance: Evidence from the Labour Market.” Oxford Review of Economic Policy 15, no. 4 (1999): 121-38.

Eichengreen, B, and P. Vazquez. “Institutions and Economic Growth in Postwar Europe.” In Productivity, Technology, and Economic Growth, edited by Bart van Ark, Simon K. Kuipers, and Gerhard H. Kuper, 91-128. New York: Springer US, (2000).

Flanagan, R. J. "Macroeconomic Performance and Collective Bargaining: an International Perspective." Journal of Economic Literature 37, September (1999): 1150-1175.

Freeman, R.B. “Labor Market Institutions Around the World.” Working Paper No.13242. Cambridge: National Bureau of Economic Research, (2007). 
Gerber, L. G. "Corporatism in Comparative Perspective: The Impact of the First World War on American and British Industrial Relations.” Business History Review 62, no. 1 (1988): 93-127.

Hassel, A. "The Politics of Social Pacts.” British Journal of Industrial Relations 41, no. 4 (2003): $707-$ 726.

Hassel, A. "Policies and Politics in Social Pacts in Europe." European Journal of Industrial Relations 15, no. 1 (2009): 7-26.

Hausman, J. A. and W. E. Taylor. "Panel Data and Unobservable Individual Effects.” Econometrica 49, no. 6 (1981): 1377-1398.

Hemker, B.T., K. Sijtsma, and I.W. Molenaar. "Selection of unidimensional scales from a multidimensional item bank in the polytomous Mokken IRT model." Applied Psychological Measurement 19, no. 4 (1995): 337-352.

Hsiao, C. Analysis of Panel Data. Cambridge: Cambridge University Press, (2003).

Huberman, M, and C. Minns. “'The Times They Are not Changin': Days and Hours of Work in Old and New Worlds, 1870-2000.” Explorations in Economic History 44, no. 4 (2007): 638-567.

Layard, R.G., S. J. Nickell, and R. Jackman. Unemployment: Macroeconomic Performance and the Labour Market. Oxford: Oxford University Press, (2005).

Maier, C. S. "Preconditions for Corporatism." In Order and Conflict in Contemporary Capitalism, edited by John H. Goldthorpe, 39-59. Oxford: Clarendon Press, (1984).

Mokken, R. J. and C. Lewis. "A nonparametric approach to the analysis of dichotomous item responses." Applied Psychological Measurement 6, no. 4 (1982): 417-430. 
Nickell, S, and R. Layard. “Labor Market Institutions and Economic Performance.” In Handbook of Labor Economics, Vol. 3, Chapter 46, edited by Orley C. Ashenfelter and David Card, 3029-3084. Amsterdam: Elsevier, (1999).

OECD. Employment Outlook. Paris: OECD, (1997).

Panitch, L. "The Development of Corporatism in Liberal Democracies." Comparative Political Studies 10, no. 1 (1977): 61-90.

Plümper, T., and V.E. Troeger. "Efficent Estimation of Time-Invariant and rarely Changing Variables in finite Sample Panel Analyses with Unit Fixed Effects." Political Analysis 15, no. 2 (2007): 124-139.

Regini, M. “Tripartite Concertation and Varieties of Capitalism," European Journal of Industrial Relations 9, no. 3 (2003): 251-263.

Schroeder, W. and R. Weinert. "Designing Institutions in European Industrial Relations: A Strong Commission versus Weak Trade Unions?” European Journal of Industrial Relations 10, no. 2 (2004): 199-217.

Siegel, N. 'Social Pacts Revisited: ‘Competitive Concertation’ and Complex Causality in Negotiated Welfare State Reforms.” European Journal of Industrial Relations 11, no. 1 (2005): 107-126.

Soskice, D. "Wage Determination: The Changing Role of Institutions in Advanced Industrialized Countries." Oxford Review of Economic Policy 6, no. 4 (1991): 36-61.Traxler, F., and B. Brandl. "Collective Bargaining, Inter-Sectoral Heterogeneity and Competitiveness: A Cross-National Comparison of Macroeconomic Performance.” British Journal of Industrial Relations 50, no. 1 (2012): 73-98.

Visser, J. "Two Cheers for Corporatism, One for the Market: Industrial Relations, Wage Moderation, and Job Growth in the Netherlands.” British Journal of Industrial Relations 36, no. 2 (1998): 269-92. 
Visser, J. "ICTWSS: Database on Institutional Characteristics of Trade Unions, Wage Setting, State Intervention and Social Pacts in 34 Countries between 1960 and 2007.” Amsterdam: University of Amsterdam, (2013). http://www.uva-aias.net/208.

Wallerstein, M. "Wage-Setting Institutions and Pay Inequality in Advanced Industrial Societies." American Journal of Political Science 43, no. 3 (1999): 649-680.

Wallerstein, M, M. Golden, and P. Lange. “Unions, Employers' Associations, and Wage-Setting Institutions in Northern and Central Europe, 1950-1992'. Industrial and Labour Relations Review 50, no. 3 (1997): 379-401. 
Table 1 . Wage and labour productivity summary statistics, by country

\begin{tabular}{lccccc}
\hline weal hourly & $\begin{array}{c}\text { Real } \\
\text { output/hour }\end{array}$ & $\begin{array}{c}\text { Dispersion } \\
\text { (s.d.) of } \\
\text { sectoral } \\
\text { wages }\end{array}$ & $\begin{array}{c}\text { Real wages/ } \\
\text { productivity }\end{array}$ & $\begin{array}{c}\text { Years of } \\
\text { wage data }\end{array}$ \\
\hline Australia & $15.1(1.2)$ & $21.3(4.0)$ & $3.7(.37)$ & $.70(.06)$ & 36 \\
Austria & $14.4(2.5)$ & $19.5(5.4)$ & $3.3(.93)$ & $.76(.10)$ & 40 \\
Belgium & $16.4(4.1)$ & $26.0(6.5)$ & $3.2(2.0)$ & $.63(.08)$ & 39 \\
Canada & $21.5(2.4)$ & $22.5(3.5)$ & $4.7(.96)$ & $.98(.19)$ & 40 \\
Denmark & $18.3(5.0)$ & $22.8(5.4)$ & $1.8(1.4)$ & $.81(.08)$ & 40 \\
Finland & $12.2(1.9)$ & $19.0(6.4)$ & $2.1(.55)$ & $.69(.14)$ & 40 \\
France & $11.0(2.8)$ & $25.0(6.8)$ & $2.4(1.1)$ & $.45(.04)$ & 40 \\
Great Britain & $18.3(2.9)$ & $20.2(5.7)$ & $4.2(1.3)$ & $.80(.07)$ & 29 \\
Germany & $17.4(3.5)$ & $23.9(5.6)$ & $4.8(.88)$ & $.75(.19)$ & 40 \\
Greece & $7.8(2.1)$ & $11.5(3.0)$ & $3.8(.75)$ & $.73(.05)$ & 40 \\
Ireland & $13.0(4.3)$ & $17.1(7.7)$ & $2.9(2.0)$ & $.83(.18)$ & 40 \\
Israel & $11.8(1.1)$ & $20.5(1.2)$ & $3.8(1.4)$ & $.57(.02)$ & 16 \\
Japan & $14.4(.55)$ & $16.6(5.1)$ & $1.7(.13)$ & $.66(.03)$ & 18 \\
Netherlands & $20.5(2.2)$ & $24.8(5.6)$ & $3.4(1.3)$ & $.85(.14)$ & 40 \\
Norway & $18.1(5.9)$ & $25.3(7.9)$ & $2.1(2.2)$ & $.68(.10)$ & 36 \\
New Zealand & $12.5(.81)$ & $18.2(1.6)$ & $1.4(.83)$ & $.69(.04)$ & 40 \\
Portugal & $6.9(.64)$ & $12.1(2.7)$ & $2.3(.25)$ & $.50(.03)$ & 22 \\
Singapore & $7.5(4.3)$ & $12.4(4.8)$ & $2.3(1.6)$ & $.54(.10)$ & 40 \\
Spain & $13.8(2.0)$ & $17.8(5.1)$ & $3.8(.72)$ & $.70(.06)$ & 34 \\
Switzerland & $19.1(5.8)$ & $21.2(2.7)$ & $2.8(2.0)$ & $.79(.18)$ & 38 \\
Sweden & $13.0(1.0)$ & $22.3(4.4)$ & $1.9(.59)$ & $.61(.15)$ & 40 \\
United States & $20.7(3.1)$ & $28.2(5.4)$ & $4.7(.61)$ & $.78(.24)$ & 40 \\
\hline
\end{tabular}

Notes: See text and Appendix for source details. Means and standard deviations (in parentheses) are reported. 
Table 2 . Wage and labour productivity summary statistics, by institutional regime

\begin{tabular}{|c|c|c|c|c|}
\hline & $\begin{array}{l}\text { Real } \\
\text { hourly } \\
\text { wage }\end{array}$ & $\begin{array}{l}\text { Real } \\
\text { output/hour }\end{array}$ & $\begin{array}{l}\text { Real wages/ } \\
\text { productivity }\end{array}$ & $\begin{array}{l}\text { Dispersion } \\
\text { (s.d.) of } \\
\text { sectoral } \\
\text { wages }\end{array}$ \\
\hline National level wage bargaining & $13.5(4.3)$ & $18.6(6.5)$ & $.74(.14)$ & $2.4(1.6)$ \\
\hline $\begin{array}{l}\text { Industry and 'local' level wage } \\
\text { bargaining }\end{array}$ & $15.4(5.4)$ & $22.1(6.9)$ & $.71(.18)$ & $3.2(1.7)$ \\
\hline Government imposed wages & $14.7(5.4)$ & $17.3(7.4)$ & $.76(.19)$ & $2.0(1.7)$ \\
\hline Government in tripartite negotiations & $11.7(4.8)$ & $17.7(7.2)$ & $.66(.13)$ & $2.6(1.5)$ \\
\hline $\begin{array}{l}\text { Government has indirect or no } \\
\text { involvement in bargaining }\end{array}$ & $15.9(4.9)$ & $21.6(6.3)$ & $.73(.18)$ & $3.2(1.7)$ \\
\hline
\end{tabular}


Table 3. Bargaining regime and relative wages

\begin{tabular}{|c|c|c|c|c|}
\hline Variables & $\begin{array}{c}\text { OLS } \\
(1)\end{array}$ & $\begin{array}{l}\text { FE } \\
(2)\end{array}$ & $\begin{array}{l}\mathrm{RE} \\
(3)\end{array}$ & $\begin{array}{l}\mathrm{HT} \\
(4)\end{array}$ \\
\hline National level wage bargaining & $\begin{array}{l}.023 \\
(.025)\end{array}$ & $\begin{array}{l}.011 \\
(.012)\end{array}$ & $\begin{array}{l}.011 \\
(.012)\end{array}$ & $\begin{array}{l}.011^{* *} \\
(.005)\end{array}$ \\
\hline Government imposed wages & $\begin{array}{l}-.031 \\
(.022)\end{array}$ & $\begin{array}{l}-.001 \\
(.014)\end{array}$ & $\begin{array}{l}.001 \\
(.014)\end{array}$ & $\begin{array}{l}.001 \\
(.007)\end{array}$ \\
\hline Tripartite negotiations & $\begin{array}{c}-.068 * * \\
(.028)\end{array}$ & $\begin{array}{c}-.033 * * * \\
(.014)\end{array}$ & $\begin{array}{c}-.033 * * * \\
(.014)\end{array}$ & $\begin{array}{c}-.033 * * * \\
(.006)\end{array}$ \\
\hline GDP/capita & $\begin{array}{l}.006^{*} \\
(.003)\end{array}$ & $\begin{array}{l}-.005 \\
(.006)\end{array}$ & $\begin{array}{l}-.005 \\
(.006)\end{array}$ & $\begin{array}{c}-.005^{* * * *} \\
(.001)\end{array}$ \\
\hline Constant & $\begin{array}{l}.814 * * * \\
(.047)\end{array}$ & $\begin{array}{l}.861 * * * \\
(.064)\end{array}$ & $\begin{array}{l}.840^{* * * *} \\
(.072)\end{array}$ & $\begin{array}{c}.770^{* * * *} \\
(.061)\end{array}$ \\
\hline Time trend & $\mathrm{Y}$ & Y & Y & Y \\
\hline Unit of pay controls & Y & $\begin{array}{l}\mathrm{Y} \\
\mathrm{V}\end{array}$ & Y & $\begin{array}{l}\mathrm{Y} \\
\mathrm{V}\end{array}$ \\
\hline $\begin{array}{l}\text { Sector and country controls } \\
\text { R-square }\end{array}$ & .12 & $\mathrm{Y}$ & $\mathrm{Y}$ & $\mathrm{Y}$ \\
\hline R-square within & & .28 & .27 & \\
\hline R-square between & & .01 & .71 & \\
\hline $\begin{array}{l}\text { R-square overall } \\
\text { rho }\end{array}$ & & .13 & .61 & .68 \\
\hline Number of observations & 4906 & 4906 & 4906 & 4906 \\
\hline
\end{tabular}


Table 4. Bargaining regime and wage dispersion

\begin{tabular}{lcccc}
\hline Variables & OLS & FE & RE & HT \\
& $(1)$ & $(2)$ & $(3)$ & $(4)$ \\
\hline National level wage bargaining & .220 & .479 & .480 & $.480^{* *}$ \\
& $(.291)$ & $(.295)$ & $(.300)$ & $(.228)$ \\
Government imposed wages & $-.470^{*}$ & $-.461^{* *}$ & $-.461^{* *}$ & $-.461^{* * *}$ \\
& $(.259)$ & $(.232)$ & $(.236)$ & $(.151)$ \\
Tripartite negotiations & -.078 & -.210 & -.210 & -.210 \\
& $(.266)$ & $(.212)$ & $(.216)$ & $(.141)$ \\
GDP/capita & .082 & .148 & .148 & $.148^{* * *}$ \\
& $(.053)$ & $(.096)$ & $(.098)$ & $(.062)$ \\
\hline Constant & 1.040 & -.144 & -.738 & $-.738^{* *}$ \\
& $(.780)$ & $(.943)$ & $(1.035)$ & $(.315)$ \\
Time trend & $\mathrm{Y}$ & $\mathrm{Y}$ & $\mathrm{Y}$ & $\mathrm{Y}$ \\
Unit of pay controls & $\mathrm{Y}$ & $\mathrm{Y}$ & $\mathrm{Y}$ & $\mathrm{Y}$ \\
Country controls & & $\mathrm{Y}$ & $\mathrm{Y}$ & $\mathrm{Y}$ \\
R-square & .34 & & & \\
R-square within & & .44 & .44 & \\
R-square between & & .02 & .99 & \\
R-square overall & & .26 & .70 & .00 \\
rho & & & & 732 \\
Number of observations & 732 & 732 & 732 & \\
\hline
\end{tabular}

Notes: Coefficients and standard errors (in parentheses) are reported. All regressions are clustered by unit of observation and robust standard error estimator is applied. Models are estimated by Ordinary Least Squares (OLS), Fixed Effects (FE), Random Effects (RE), and Hausman-Taylor (HT) regression models. In the Hausman-Taylor (HT) model, bargaining states and GDP are treated as time-varying endogenous variables. Level of significance is denoted as follows: $* * * 1 \%, * * 5 \%, * 10 \%$. 
Table 5. Bargaining regime and wage outcomes - historical and contemporary institutional effects

\begin{tabular}{lcc}
\hline Variable & Wage moderation & Wage dispersion \\
\cline { 2 - 3 } & $(1)$ & $(2)$ \\
\hline National level wage bargaining (residuals) & $.013^{* * *}$ & $.469^{* *}$ \\
Government imposed wages (residuals) & $(.005)$ & $(.230)$ \\
& .001 & $-.480^{* * *}$ \\
Tripartite negotiations (residuals) & $(.006)$ & $(.154)$ \\
& $-.036^{* * *}$ & -.203 \\
Historic wage coordination & $(.005)$ & $(.143)$ \\
& $-.322^{* * *}$ & $-1.951^{* * *}$ \\
GDP/capita & $(.136)$ & $(.665)$ \\
& $-.017 * * *$ & $.128^{* * *}$ \\
Constant & $(.001)$ & $(.030)$ \\
Time trend & $1.422^{* * *}$ & $-3.492^{* * *}$ \\
Unit of pay controls & $(.223)$ & $(1.236)$ \\
Sector controls & $\mathrm{Y}$ & $\mathrm{Y}$ \\
Country controls & $\mathrm{Y}$ & $\mathrm{Y}$ \\
rho & $\mathrm{Y}$ & $\mathrm{Y}$ \\
Number of observations & $\mathrm{Y}$ & .00 \\
\hline
\end{tabular}

Notes: The Hausman-Taylor (HT) estimator is applied. Coefficients and standard errors (in parentheses) are reported. Models are estimated by Ordinary Least Squares (OLS), Fixed Effects (FE), Random Effects (RE), and Hausman-Taylor (HT) regression models. Bargaining states and GDP are treated as time-varying endogenous variables. Israel and Singapore are excluded from this regression model due to lack of historic data in Allard and Lindert (2006). Level of significance is denoted as follows: *** $1 \%, * * 5 \%, * 10 \%$. 


\section{Appendix 1. Sources for institutional variables, wages, and other data}

\section{Wage data}

Information on wages is drawn from the ILO's LABORSTA database. We began by extracting wage information from 1969 to 2008 (when available for those years, as discussed below) for the following countries: Australia, Austria, Belgium, Canada, Denmark, Spain, Finland, France, Great Britain, Germany (West then unified), Greece, Ireland, Israel, Italy, Japan, Netherlands, Norway, New Zealand, Portugal, Singapore, Sweden, Switzerland, and the United States. Of this initial selection, we retain all earnings series that consist of actual earnings or wages paid - we leave aside pay measures derived from the scales of collective agreements, minimum wages or salaries, and the like. In the next step, we convert all pay series into US dollar equivalents, using exchange rate data to convert from local currencies. ${ }^{44}$ The wage series are then converted to 2000 dollars using similar information about historical US consumer price indices. ${ }^{45}$ A final conversion relates to units of pay, which were recorded as earnings or wages per hour, day, week, or month. All series were converted to hourly in the work that follows. Visual inspection of the surviving series suggested that wages for some series were implausibly high or low, regardless of adjustments made for currency or time worked. Several series for Austria, Belgium, Canada, Germany, Finland, and the United States were discarded. All data for Italy was omitted due to the implausible wage numbers. The final task was to gather the wage series by sector. The indicators used by the ILO differ somewhat by survey methodology, but data was coded into the following groupings to the best of our ability: manufacturing, construction, trade, transportation, finance, community, primary, mining, energy, and "other". 


\section{Institutional variables}

The institutional variables are drawn from the ICTWSS Database on Institutional Characteristics of Trade Unions, Wage Setting, State Intervention and Social Pacts in 34 Countries Between 1960 and 2008. The database was created by Jelle Visser in the Amsterdam Institute for Advanced Labour Studies (AIAS) at the University of Amsterdam. We use the most recently available version of the database, released on-line on May 3, 2011. The variables we use from the ICTWSS database are the following: coordination of wage bargaining (WCOORD, $1,2,3,4,5)$, government intervention in wage bargaining (GOVINT, 1,2,3,4,5), level at which wage bargaining takes place (LEVEL, 1,2,3,4,5), mandatory extension of collective agreements (EXT, 0,12), national minimum wage (NMW, 0,1,2), union density (UD, 0-100), adjusted bargaining coverage (ADJCOV, 0-100), and centralisation of wage bargaining (CENT, 0-100). The bargaining and government intervention variables were used to construct a series of dummy variables to capture different bargaining states. Institutional measures from the 1950s are from Allard and Lindert's coordination index, which we have rescaled from 0 to $2 .{ }^{46}$

\section{Other variables}

Labour productivity is from the Groningen Growth and Development Centre. It consists of GDP per hour, expressed in 1990 Geary-Khamis US dollars. 


\section{Appendix 2: Estimation methodology}

The simplest strategy to estimate the models in equation (1) is using pooled OLS (ordinary least squares) regression. However, OLS would produce results that do not correspond to the causal effects of bargaining regimes and country institutions on labour market outcomes if both bargaining regimes and country institutions are endogenous so that we may be capturing reverse causality or the effect of some omitted variables on both bargaining regimes and labour market outcomes. If we treat the bargaining regime variables as exogenous and ignore the measurement error problem the coefficients on these variables will be typically biased upwards. If the measurement error in bargaining regime variables is significant, their coefficients might be biased downward due to attenuation bias. A related problem can arise if bargaining regime variables correspond only poorly to the desired concept. Our Mokken's nonparametric scaling analysis was intended to minimise this attenuation bias. In robustness check analysis where we use 5-year averages of the time series we further address the measurement error problem and show, as we will discuss later, robustness of our results.

The traditional technique to overcome the problems outlined above is to eliminate the individual effects in the sample by transforming the data into deviations from individual means. Unfortunately, the resulting within-groups or fixed effects (FE) estimator has two important defects: 1) all time-invariant variables are eliminated by the transformation, so that fixed effect (institutions) coefficients cannot be estimated, and 2) the within-groups estimator is not fully efficient since it ignores variation across countries (and industries). Furthermore, the fixed effects soak up most of the explanatory power of the slowly changing variables. The alternative to FE is the RE (random effects) model. However, the RE model even though more efficient than the pooled OLS is also inconsistent and biased when regressors are correlated with (latent) 
fixed effects. Importantly, the second drawback of the FE model becomes very serious in the case of variables that have very little within variance such as the bargaining regime dummy set in our analysis that show much more variation across countries than over time. This inefficiency leads to highly unreliable point estimates and may thus cause wrong inferences in the same way a biased estimator could.

A reasonable compromise in these circumstances is offered by the Hausman-Taylor procedure and the FEVD (fixed effects vector decomposition) procedure of Plümper and Troeger. ${ }^{47}$ The Hausman-Taylor procedure estimates a RE model and relies on exogenous timevarying variables as instruments for the endogenous time-varying variables and exogenous timeinvariant variables plus the means of the exogenous time-varying variables as instruments for the endogenous time-invariant variables. The Hausman-Taylor procedure provides a consistent solution to the potentially severe problem of correlation between (latent) fixed effects and timeinvariant variables. However, caution must be exercised in identifying instruments that are uncorrelated with the errors and the fixed effects and highly correlated with the endogenous regressors. An important feature of the Hausman-Taylor procedure is that the non-correlation assumptions can be tested, so that the method need not rely on totally a priori assumptions. FEVD decomposes the latent FE into an unexplained part and a part explained by the time invariant or the rarely changing variables. The procedure is similar to that suggested by Hsiao but applied to small sample TSCS data. ${ }^{48}$ 
Appendix Table A1. Level of wage bargaining and intensity of government involvement 19692008

\begin{tabular}{lccc}
\hline & $\begin{array}{c}\text { Level of wage } \\
\text { bargaining } \\
\text { (national 1; } \\
\text { other 0) }\end{array}$ & $\begin{array}{c}\text { Government } \\
\text { involvement } \\
\text { (imposed } \\
\text { wages 2; } \\
\text { tripartism 1; } \\
\text { other 0) }\end{array}$ & $\begin{array}{c}\text { Corporatism } \\
\text { index 1950s } \\
\text { (high 2; low 0) }\end{array}$ \\
\hline Australia & .35 & \\
Austria & $.22(.42)$ & $.35)$ & 1.0 \\
Belgium & $.35(.48)$ & $.25(.26)$ & 2.0 \\
Canada & $.46(.50)$ & $1.00(.92)$ & 1.0 \\
Denmark & $.00(.00)$ & $.15(.53)$ & .0 \\
Finland & $.10(.30)$ & $.35(.77)$ & 2.0 \\
France & $.75(.44)$ & $.90(.54)$ & .5 \\
Great Britain & $.00(.00)$ & $.15(.53)$ & 1.0 \\
Germany & $.10(.30)$ & $.38(.70)$ & 1.5 \\
Greece & $.00(.00)$ & $.00(.00)$ & 1.5 \\
Ireland & $.62(.49)$ & $.72(.72)$ & .0 \\
Israel & $.72(.45)$ & $.60(.50)$ & 1.0 \\
Japan & $.22(.42)$ & $.15(.43)$ & - \\
Netherlands & $.00(.00)$ & $.00(.00)$ & 1.5 \\
Norway & $.50(.51)$ & $.50(.75)$ & 2.0 \\
New Zealand & $.70(.46)$ & $.52(.72)$ & 2.0 \\
Portugal & $.48(.50)$ & $.65(.95)$ & 1.5 \\
Singapore & $.12(.33)$ & $.75(.87)$ & 2.0 \\
Spain & $.00(.00)$ & $1.0(.00)$ & - \\
Switzerland & $.15(.36)$ & $.65(.80)$ & 2.0 \\
Sweden & $.00(.00)$ & $.00(.00)$ & 1.0 \\
United States & $.50(.51)$ & $.10(.30)$ & 2.0 \\
\hline
\end{tabular}

Notes: See text and Appendix for source details. The corporatism index is rescaled from 3-1 to 2-0 range. Means and standard deviations (in parentheses) are reported. 
Appendix Table A2: Auxiliary regressions for estimating residuals

\begin{tabular}{lcccc}
\hline Dependent variable & \multicolumn{2}{c}{$\begin{array}{c}\text { Wage-productivity } \\
\text { gap }\end{array}$} & \multicolumn{2}{c}{ Wage dispersion } \\
\cline { 2 - 5 } & \multicolumn{2}{c}{$(1)$} & \multicolumn{2}{c}{$(2)$} \\
\cline { 2 - 5 } & Coefficient & $\mathrm{R}^{2}$ & Coefficient & $\mathrm{R}^{2}$ \\
\hline National level wage bargaining & $.144^{* * *}$ & .14 & $.190^{* *}$ & .05 \\
& $(.029)$ & & $(.092)$ & \\
Government imposed wages & $.206^{* * *}$ & .21 & $.157^{* * *}$ & .22 \\
& $(.073)$ & & $(.024)$ & \\
Tripartite negotiations & $.193^{* * *}$ & .27 & $.191^{* * *}$ & .27 \\
& $(.021)$ & & $(.066)$ & \\
\hline
\end{tabular}

Notes: All regressions are clustered by unit of observation and robust standard errors OLS estimator is applied. The sole explanatory variable in each regression is the historic index of wage coordination. Level of significance is denoted as follows: *** $1 \%, * * 5 \%, * 10 \%$. 